\title{
The Investigation relationship between Social support and Depression mediated by Loneliness between Elderly
}

\author{
Mirderikvand $\mathrm{F}^{1}$, Adavi $\mathrm{H}^{2}$, Amirian $\mathrm{L}^{3}$, Khodaie $\mathrm{S}^{4}$
}

\begin{abstract}
Introduction and purpose:Depression is effect by several psychological factors, that from most important can be note social support and loneliness noted. Therefore this research aimed to predict depression based on the mediating role of social support loneliness among the elderly.

Materials and Methods: This is a descriptive study of correlational type. The statistical population of this research included all elderly of Khorramabad City in 2016 year that from them 100 elders was selected by convenience sampling method. Data collection tools included the questionnaires Beck Depression ( 1961), Social Support (wax \& et al, 1986), loneliness Russell (1966) that were completed by samples. Data was analyzed by using the SPSS-24 software and correlation and multiple regressions with enter model methods.

Findings: The results indicated that: the subscales of family support and friend support negatively predict depression. The subscales of social support, negatively predict loneliness.

Conclusion: According to the findings of this research social support mediated by loneliness can affect depression. Therefore, the role of these variables in predicting depression, the results can provide useful information to reduce depression and loneliness in old people's families.
\end{abstract}

Key words: Social Support, Depression, Loneliness, Elderly, Khorramabad

Received: 2017/01/8

Accepted: 2017/02/14

Copyright $\odot 2018$ Quarterly Journal of Geriatric Nursing.This is an open-access article distributed under the terms of the Creative Commons Attribution international 4.0 International License(http://creativecommons.org/licenses/by /4.0/) which permits copy and redistribute the material, in any medium or format, provided the original work is properly cited.

1- Assistant Professor of Psychology, Department of Humanities, University of Lorestan, Iran

(Corresponding Author):E-mail:mirfazlolah@yahoo.com

2 -PhD student in Educational Psychology, Faculty of Art, University of Lorestan, Iran

$3-\mathrm{PhD}$ student in Educational Psychology, Faculty of Art, University of Lorestan, Iran

$4-\mathrm{PhD}$ student in Educational Psychology, Faculty of Art, University of Lorestan, Iran 


\title{
بررسى رابطه بين حمايت اجتماعى و افسردكى با نقش ميانجى احساس تنهايى در بين سالمندان
}

\author{
فضل اله ميردريكوند"'، حميده اداوى بَ، ليلا اميريان"، سجاد خدايىع
}

تاريخ دريافت مقاله: 199

تاريخ يذيرش مقاله: عץ / / / هوسו

مقدمه و هدف: ميزان افسردگى تحت تأثير عوامل روانشناختى زيادى است كه از مهمترين آنها مستـوان بـه حمايـت اجتمـاعى و

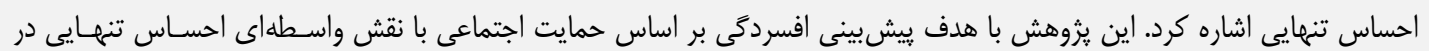
بين سالمندان انجام شد. مواد و روش ها: اين يُوهش توصيفى از نوع همبستخى بود. جامعه آمارى اين يزوهش، شامل كليه سالمندان شهرستان خـرمآبـاد در

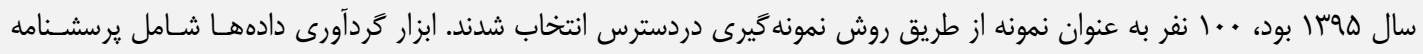

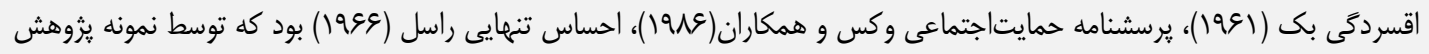

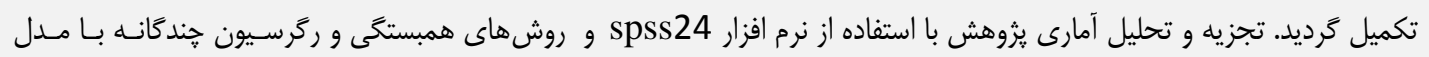
همزمان انجام گرفت. يافتهها: نتايج نشان داد كه: ابعاد حمايت خانواده و حمايت دوستان به صورت منفى افسردگى را ييشبينس مسى كنــد. همجنـين ابعـاد حمايت اجتماعى، احساس تنهايى، را بهصورت منفى ييشينى مى كنند.

نتيجه كَيرى: با توجه به يافتههاى اين يزوهش متغير حمايت اجتماعى با واسطهى احساس تنهايى مى تواند بر افسـردمى اثر بخــارد.

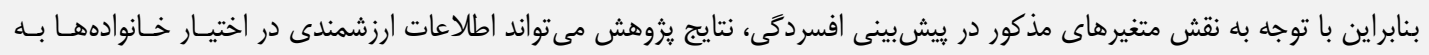
منظور كاهش افسردگى و احساس تنهايى سالمندان قرار دهد. كليدوازه: حمايت اجتماعى ، افسردگى، احساس تنهايى، سالمندان، خرمآباد

ا- استاديار روانشناسى تربيتى، دانشكده ادبيات و علوم انسانى، دانشكاه لرستان، خرم آباد، ايران (نويسنده مسؤول). پِيست الكترونيكى: mirfazlolah@yahoo.com

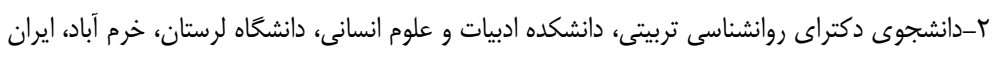

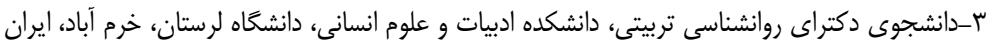

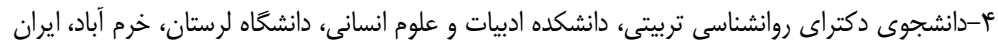


مجموعه تغييراتى كه با افزايش سن بـه خصـوص بـا نزديـك شدن به دوره سالمندى به وقـوع مسي ييوندنـد، از قبيـل مـرى

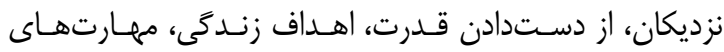
جسمانى و موقعيت اجتماعى مسائل خاص اين دوره تحـولى را به وجود مى آورد كه نيازمند توجه ويزماى است. مجموعـه ايـن تغييرات و نزديكى شدن بـه روزهـاى وايـانى زنـــى و مـرى، فشارهاى خاصى را بر افراد سالمند تحميل مى كند كه از ايـن ميان دو مورد افسـردحىى' و احســاس تنهـايى '، كـه در ارتبـاط تنكاتنكى با هم هستند قابل توجه مى باشند. برخى از محقّقين، شيوع بالاى افسردگى را در سنين هه الى عاع سال نشان دادهاند

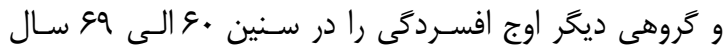
كزارش نمـودهانـــــ تشـخيص شـاخصهــــ خلـق افسـرده در سالمندان بسيار دشوار اسـت جـرا كـه نشـانغان افسـردى در سالمندى با دوره جوانى متفاوت اسـت. ريشـــ ايـن تفــاوتهــا مىتواند در تجربههاى افسردساز ماننداغدارى، بيمـارىهـاى دردناك و يا منتج از اختلالات شناختى مانند نقصحافظه باشـــ [ه]. افسردحى دوره سالمندى، به عنوان دومين علّت ناتوانىهاى اين دوره، بعد از علل جسمانى برآورد شده است كه و ميليون از آمريكايىهاى 9 9 ساله را تحت تأثير قرار داده است. فرادى كه

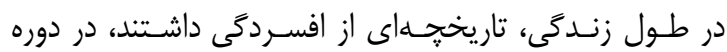
سالمندى افسردگى مضاعف از خود نشان دادند [ع]. افسردگى يكى اختلال خلقى است كـه خـود را بــا عالائمسى نظير خلق پايين، از دست دادن احساس لذت و علاقـه، كـاهش

1 depression 2 Loneliness
امروزه سالمندى به يك يديده مهم جهانى تبـديل شـده اسـت، زيرا به سبب افزايش اميد به زندكى و مسـائل بهداشـتى، طبـق آمار سازمان بهداشت جهانى، جمعيت اين حـروه افزايش يافتـهـ است. بر اساس برآوردهاى انجام شده، سالانه حدود / /ه درصـــ به طور متوسط به تعداد افراد هو ساله و بيشتر افزوده مسىــود؛ اما به رغم رشد جمعيت سالمندان هنوز دربـاره نيازهـاى ايشـان تمركز كـافى نشـده اسـت. بنـابراين، تـأمين بهداشـت روانسى و جسمانى سالمندان به عنوان يك كروه آسيبيذير جامعـه، توجـهـ ويزهاى را مىطلبد [1]. بديده سالمندى كه مطابق تعريف سازمان بهداشت جهانى از • سالخى به بعد اطلاق مىشود نتيجه سير طبيعى زمان است كـه منجر به تغييرات فيزيولوزيكى، روانسى و اجتمـاعى در سـالمندان

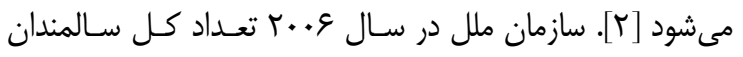
جهان را 9NV ميليون و سبو هزار نفر عنوان كرده است كه ايـن تعداد در سال •ه+r به رقم يك ميليسارد و ^و9 ميليـون و سها هزار نفر خواهد رسيد [ب[]. شاخص هاى آمـارى نشـان مسىدهنـــــــهـ رونــــــــالمند شــن جمعيت، در كشور ما نيز آغاز شده و ييشبينى مسىشود كـه در فاصله •r ساله از هVIا تا هوجا به ميانه سنى جمعيـت كشـور • ال سال افزوده مىشود. به كزارش مركز اطلاعات سازمان ملـل متحد در تهران تعداد سالمندان ايران در سال •ه+r به رقمه عץ ميليون و س.ب هزار نفر يعنى عץ درصد از كـل جمعيـت خواهــــ رسيد. طبق آمار مذكور مىتوان كفت ايران در شـرايط فعلى در حال كَذر از جمعيت جوان به جمعيت ميانسال اسـت و بـه زودى به جمع كشورهاى با تركيب جمعيت يِير خواهد ييوست [F]. 
اجتماعى بخصوص در قشر سالمندان در جهت مقابله مشـكلات روان شناختى آن ها از جملــهـ افسـردمى و اضـطراب از اهميـت

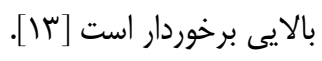

حمايت اجتماعى، قابليت و كيفيت ارتباط با ديخران است كه منابعى را در مواقع نياز فراهم مى كنــــ. حمايـت اجتمـاعى يـى كمـك دو جانبـهـ اسـت كـهـ سـبب ايجـاد خودينـداره مثبــ، خويشتنيذيرى، احساس عشق و حرمت نفس مى شود و در همه اين موارد به فرد فرصت خودشـكوفايى و رشـــ مسىهـــــ] [10]. يزوهش هاى متعددى وجـود رابطـهـه معنـادار بـين حمايـتهـاى اجتماعى و عاطفى با رفتارهاى بهزيستى و كـاهش نشـانههـاى

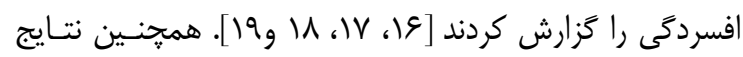
يزوهشهاى ديكرى نشان داد حمايت اجتماعى، تأثير معنـادارى بـر احسـاس تنهـايى، ســلامت عمـومى، شـادى، افسـردگى و رضايتمندى سالمندان از زندگى دارد [ · و • •l]. صاحبنظران معتقدند هر كوششى كه منجر به رفع احساس تنهايى سالمندان شود، سدى در برابر موج مشكلات يِيجيده روانى سالمندان و از طرف ديخر باعث بهبود عزت نفس آنان مىشـود [ (r]]. ماهيـت انسان به طور طبيعى اجتماعى است. نيـاز بــه تعلـق داشـتن، در

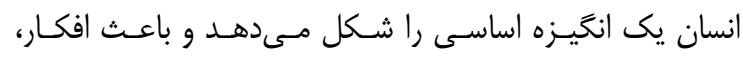
هيجانات و رفتارهاى بينفردى مىشـود [بr]. ايـن نيـاز شـامل

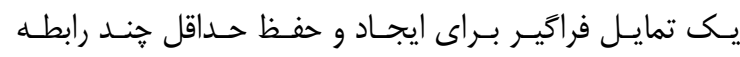
بينفردى مثبت، پايدار و مهم است. در حـالى كـهـ تفـاوتهـاى فردى در شدت نياز تعلق داشتن و جِكونكَى بـرآوردن آن وجـود دارد، ارضاء آنى نياز مستلزم تعاملات مثبت و زياد با افـراد ديخــر در يكى موقعيت بادوام است كه منجـر بـهـ سـعادت و شـادكامى طرفين مىشود. بنابراين، افرادى كه در برقرارى و حفـظ روابـط
وزن، بـى خـوابى، احسـاس خسـتخىى، احسـاس ״ـوجِى، كنـدى سايكوموتور، احساس كناه و ناتوانى در تمركز و افكار مربـوط بــهـ مرك نشان مىدهد [V]. افسردگى از تعامل بـين جنــدين عامـل مختلف حاصل مىشود كه از اين عوامل مىتوان به رويـدادهاى منفى اخير در زندگى، پايين بودن سطح حمايت اجتمايى ' اشـاره كرد [^]. افراد افسرده بيشتر از افراد غيرافسرده با افكارى دربـاره ناخشـنودى شخصـى، انتظـارات منفـى، عـزتنفـس يـايين و درماندگى درگير هستند [9]، و كمتر از حمايت اجتماعى برخوردار هستند. حمايت اجتماعى بايين را مسىتـوان بـه عنـوان يكسى از عوامل ييشبينى كننده افسردگى در نظر گرفت [• [1]. بطور كلى مى توان كفت كه فقدان روابـط اجتمـاعى مثبـت مـىتوانـد بــهـ حالتهاى روانشناختى منفى، نظير اضطراب يا افسردگى منجـر شود. همجنين حمايت اجتماعى خانواده، سلامت روانسى افراد را

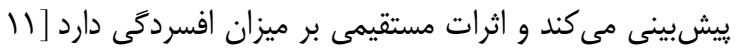
وrIr]]. حمايست اجتمـاعى بــه عنـوان يكـى از عوامـل اجتمـاعى تعيين كننده سلامت روانى در سالهـاى اخيــر توجـه فزاينـدهاى بلهدست آورده است. انسان موجودى اجتماعى اسـت و در طـول حيات خويش نيازمنـــ همنوعـان خـود اسـتـــــــن نيازمنـدى از جنبههاى مختلف و صورتهاى متفـاوتى قابـل مشـاهده اسـت. كوب[سا11] حمايست اجتمـاعى را تحـت عنـوان معرفتى اظهـار مىدارد كه افزايش روزافزون تعداد مقالات جاٍ شده در مجلات مختلـف در مـورد حمايست اجتمـاعى، اثـرات مثبـت حضـور و

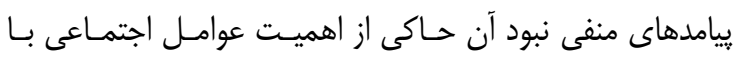
توجه به نقـش مهمسى اسـت كـه در زنــدىى انسـان دارد [II].

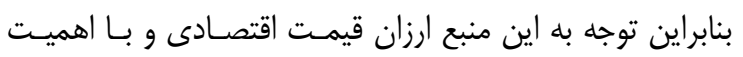


درصد كل جمعيت بالاى هاء سال را بـر حسب سـن و جـنس

$$
\text { تحت تأثير قرار مىدهد [Cr]. }
$$

احساس تنهـايى، انـزوا و ناميـدى، از مهمتـرين و شـايع تـرين

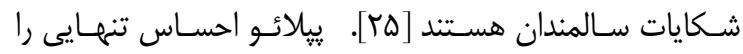

احساس ناخوشايندى مىدانــــــه در نتيجــهـ كاسـتى در شـبكه

روابط اجتماعى فرد به صورت كمى و كيفى و عدم دسترسى بـهـ

روابط نزديك و مطلوب با ديگران به وجود مىآيد [عr]. احساس

تنهايى، بــهـ مجموعـه يِيجيـدهاى از احسـاسهـا و شـناختهـا،

يريشانى ها و تجربه هيجانهاى منفى اسـت كـه از كمبودهـاى

ادراكشده فردى در روابط خصوصى و اجتماعى ناشى مسىــود

با توجه به آنجه كَته شد و اهميت دوره سالمندى و ضـرورت و

اهميت برنامهريزى به منظور بررسى و شناخت عوامل مرتبط بـاــا

زندَى سالمندان، اين يزوهش در يـى بررسى اين موضـوع اسـت كه آيا حمايت اجتماعى با افسردگى در سـالمندان رابطـه دارد و آيا احساس تنهايى در رابطـهـه ميـان حمايست اجتمـاعى اداراك و

$$
\text { افسردگى سالمندان نقش ميانجى دارد؟ }
$$

رضايت بخش با ديخران ناتوان هستند و در نتيجـهـ در بـرآوردن نياز تعلق داشتن مشكل دارند، احتمالا حس محروميتى را تجربه مى كنند كه خود را با احساس تنهايى نشان مىدهد [بr]. در حقيقت مجموعه تغييراتى كه با افزايش سن به خصوص با نزديك شدن به دوره سالمندى به وقوع مسىييوندنـد، از قبيـل مرك نزديكان، از دست دادن قدرت، اهداف زندگى، مهارتهاى جسمانى و موقعيت اجتماعى مسائل خاص اين دوره تحـولى را به وجود مىآورد كه نيازمند توجه ويزماى است. مجموعـه ايـن

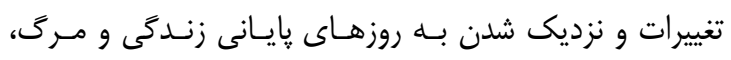
فشارهاى خاصى را بر افراد سالمند تحميل مى كند كـهـ از ايـن ميـان دو مـورد افسـردمى و احسـاس تنهـايى، كـه در ارتبـاط تنكاتنكى با هم هستند قابل توجه مى باشند [ه]. احساس تنهايى به عنوان يكى از نشانه هاى افسردگى و نيز به عنوان يك عامل مستقل در ايجـاد آسـيبهـاى روانشـناختى سالمندى مورد توجه بوده است و از ديد سـالمندان، بـه دلايـل مختلف از قبيل نقصهاى جسـمى، از دسـت دادن نزديكـان و كمرنگ شدن ارتباطات تجربه مىشود. شواهد نشان مسدهنـــ

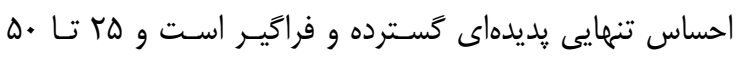




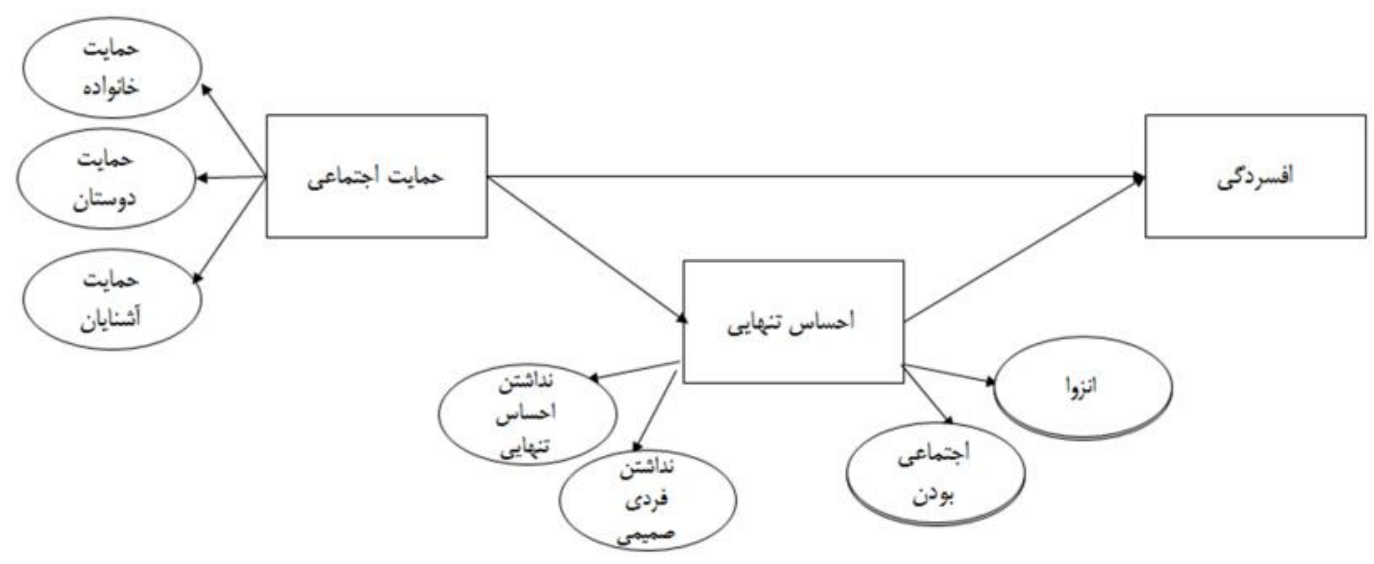

مدل مفهومى يزوهش حاضر

ركرسيون جندكانه مطابق با روش بارون و كنى (عدوا) استفاده

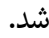

\section{جامعه آمارى، نمونه و روش نمونهَيرى}

جامعه آمارى شامل تمام سالمندان سـاكن در سـراى سـالمندان شهر خرمآباد، مىباشد. نمونه يزوهش حاضر ..1 نفر بود. روش كار به اين صورت بود كه، از بين كل سالمندان كسانى كه قـادر به پاسخ كَيى بودند، به عنوان نمونه يُوهش انتخاب شدند.

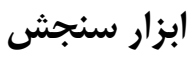

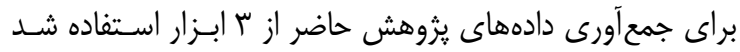
كه در ادامه به معرفى آنها يرداخته شده است.
مواد و روشها

يزوهش حاضر از نـوع توصـيفى - همبسـتخى اسـت، كـه در آن حمايت اجتماعى به عنوان متغير برونزاد و احساس تنهـيى بــــ عنوان متغير واسطهاى و افسردَى به عنوان متغيـر درونزاد، در نظر كَرفته شدهاند. بـراى اجـراى يرسشـنامههـا ابتـدا از ادارهى بهزيستى شهرستان خرمآباد، براى پِخـش پرسشـنامهــا مجـوز كَرفته شد، و دو مركز سالمندان انتخاب شد و يرسشنامهها ميـان سالمندانى كه قادر به باسخ كَويى بودند، پֶخ شد. براى تجزيـهـ و تحليل اطلاعات، ابتدا از شاخصهاى آمار توصيفى استفاده شد و در مرحله بعد، ميزان همبسـتخى متغيرهـا مـورد بررسى قـرار كرفتـ. براى بررسى رابطه متغير مستقل، حمايـت اجتمـاعى بـر احساس تنهايى و افسردگى از روش آمارى ركرسـيون خُندكانـهـ استفاده شد. براى بررسى رابطهى واسطهاى احسـاس تنهـايى از روش تحليل مسير استفاده شد. براى بررسى اين رابطه از 


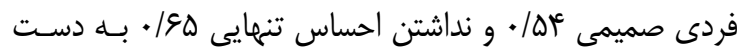

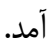

ير سشنامه افسردَّى بكى ': فرم كوتاه يرسشنامه افسـردگى

توسـط بـك (او99) بـود. ايـن يرسشـنامه شـامل سا گــزاره

خودَزارش دهى است كه نشانههـاى خـاص افسـردَى را بيـان

مسى كنــد. هـر كَـزاره ايـن يرسشـنامه شـامل يــ مقيـاس

جهار گويهاى است كه دامنه آن از صفر تا سّ مرتب شدهاسـت. در

يزوهش حاضر يايايى به روش آلفاى كرونباخ عq/.به دست آمد.
"يرسشنامه حمايت اجتماعى فيليــــ ': ايـن يرسشـنامه

توسط وكس و همكاران (عمو1) تهيه شده اسـت. ايـن مقيـاس

داراى سٓ ماده است كه سه حيطه خانواده، دوستان و آشـنايان را در برمى گيرد. مشاك همباضريب پايايى اين برسشنامه را از دو روش آلفاى كرونباخ و تنصيف به ترتيب r//• و • • محاسـبه كرده است [سץ]]. مشاك براى تعيين اعتبار اين يرسشـنامه نمـره كل آزمون و آزمون اضطراب اجتماعى را همبسته كرد و ضـريب همبستخى /VV/•- بهدست آمد. در يثوهش حاضر نيز بايـايى بـا روش آلفاى كرونباخ محاسبه شد. كـهـ بـراى حمايـت اجتمـاعى

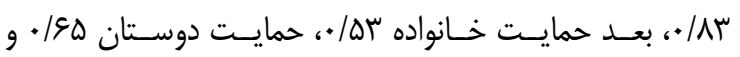
حمايت آشنايان OV/ • به دست آمد.

يرسشنامه احساس تنهايى: ايـن مقيـاس توسـط راسـل (1999) ساخته شده است. داراى • ب يرسش اسـت كـه خوانتـده بايد به هر يك از يرسشها روى مقيـاس ليكـرت جهاردرجـهاى پاسخ دهد. مقياس تنهايى نخستين بار توسط راسـل و فركوسـن تدوين شد كه بعد از سه بار ويرايش، نسخه نهايى ايسن مقيـاس در جهار كَروه دانشجويان، يرستاران، معلمان و افراد مسن، و بــــ شيوههاى مختلفى از قبيل خودَزارشدهى و مصاحبه اجرا شـده و دامنه آلفا از 19/• تا ع9/• بهدست آمده است. در افراد مسـن، يكى سال بعد باز آزمون انجام شده است و همبستخى آزمون-باز

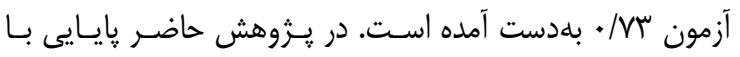
روش آلفاى كرونباخ محاسبه شــــــهـ بـراى احسـاس تنهايى

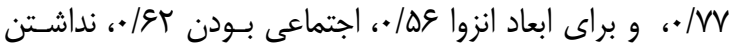

\footnotetext{
${ }^{1}$ Philips Social Support Inventory (PSSI)
}

${ }^{2}$ Beck Depression Inventory 
بافتهها

جدول ا. شاخصهاى توصيفى متغيرهاى يثوهش

\begin{tabular}{|c|c|c|}
\hline انحراف استاندارد & ميانگَين & متغير \\
\hline ع ع/r & $r M / v \Lambda$ & حمايت خانواده \\
\hline (T) & TI/אT & حمايت دوستان \\
\hline$r / \Lambda$. & 19/DT & حمايت آشنايان \\
\hline $\mathrm{M} / \mathrm{M}$ & $\mid f / \cdot V$ & انزوا \\
\hline$r / \Delta F$ & $1 r / \cdot r$ & اجتماعى بودن \\
\hline$r / g \mu$ & $1 w / \cdot \Lambda$ & نداشتن فردى صميمى \\
\hline$r / \cdot \Lambda$ & $1 \cdot / 4$ & نداشتن احساس تنهايى \\
\hline $11 / 1 r$ & rN/Dq & افسردَى \\
\hline
\end{tabular}

\section{ماتريس همبستكى صفر مرتبه بين متغيرها}

\begin{tabular}{|c|c|c|c|c|c|c|c|c|}
\hline$\Lambda$ & V & 7 & 0 & $\varepsilon$ & r & $r$ & 1 & متغير \\
\hline & & & & & & & 1 & حمايت خانواده \\
\hline & & & & & & 1 & $\cdot 19 \cdot *$ & حمايت دوستان \\
\hline & & & & & 1 & $\cdot 18 \Lambda^{*}$ & $.199^{*}$ & حمايت آشنايان \\
\hline & & & & 1 & -.1 .9 & $-\cdot / \cdot 1$ & $-\cdot / 1 \cdot$ & انزوا \\
\hline & & & 1 & $\cdot / \varphi^{*}$ & $-\cdot 1 \cdot v$ & -.1 .9 & $-\cdot / 10$ & اجتماعى بودن \\
\hline & & 1 & $\cdot / v^{*}$ & $\cdot / T V^{*}$ & $-\cdot 1 \cdot+1$ & $-\cdot / \cdot r$ & $-\cdot 1 \cdot 1$ & نداشتن فردى صميمى \\
\hline & 1 & $\cdot / / \omega^{*}$ & $\cdot / \Delta \Lambda^{*}$ &.$/ 4 *^{*}$ &.$- / 19$ & $-\cdot 1 \cdot 1$ & $-\cdot / r \Delta^{*}$ & نداشتن احساس تنهايى \\
\hline 1 &.$/ \mu V^{*}$ & $.1 . .9$ & ع ع א/. & $-\cdot / \cdot v V$ & -.1 .9 & $-\cdot \cdot \cdot v$ & $-\cdot / r \Lambda^{*}$ & افسردَّى \\
\hline
\end{tabular}

$\mathrm{P}<0 / 001$

با توجه به اين كه هدف يثوهش حاضر بررسى نقش واسطهاى

احساس تنهايى در رابطه ميـان حمايـت اجتمـاعى و افسـردگى

مىباشد، در جدول س ضرايب اثر مسـتقيم و غيرمسـتقيهم و كـل

$$
\text { متغيرهاى يثوهش آورده شده است. }
$$

نتايج مندرج در جدول ؟، همبستخى متقابـل متغيرهـا را بـا هـم

نشان مى دهد و مواد معنادار بــا علامـت ** مشـخص شـدهانـــ.

همان طور كه ملاحظه مى كنيد، دامنه همبسـتخى افسـردخى بـا متغيرها يثوهش از V• • • تا VW/ • مى باشد. 
به منظور روشن شدن بهتر و بررسى نقـش واسـطهاى احسـاس برونزاد بر افسردگى آمده است. تنهايى در جدول زيــر اثر مسـتقيم و غيـر مسـتقيم متغيرهـاى

جدول س. اثرات مستقيه، غيرمستقيم و كل متغيرهاى بزوهش بر يكديخر

\begin{tabular}{|c|c|c|c|}
\hline اثر كل & اثر غير مستقيم & اثر مستقيم & مسير ها به روى افسردَىى \\
\hline$-\cdot / N T$ &.$- / 1 \mathrm{~V}$ & $-\cdot / \Delta \Delta$ & حمايت خانواده \\
\hline \multirow[t]{3}{*}{.$-|\Delta|$} & -.1 .9 &.$- /$ AT & حمايت دوستان \\
\hline & & זس/. & اجتماعى بودن \\
\hline & & . & نداشتن احساس تنهايى \\
\hline
\end{tabular}

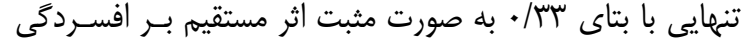

دارند. در اين راستا شكل (، مدل نهايى را نشان مىدهد در ايـن

مدل، متغيرهايى كه معنادار نبودند و ضر يب آنها كمتر از •/.

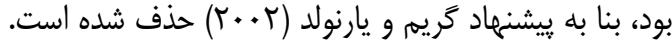

همان طور كه نتايج جدول ؟ نشان مىدهد بعد حمايـت خـانواده

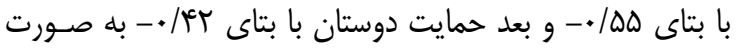
منفى اثر مستقيمى بــر افسـردگى دارد، و از بـين ابعـاد احسـاس تنهايى، بعد اجتماعى بـودن بـا بتـاى سب// • و نداشـتن احسـاس

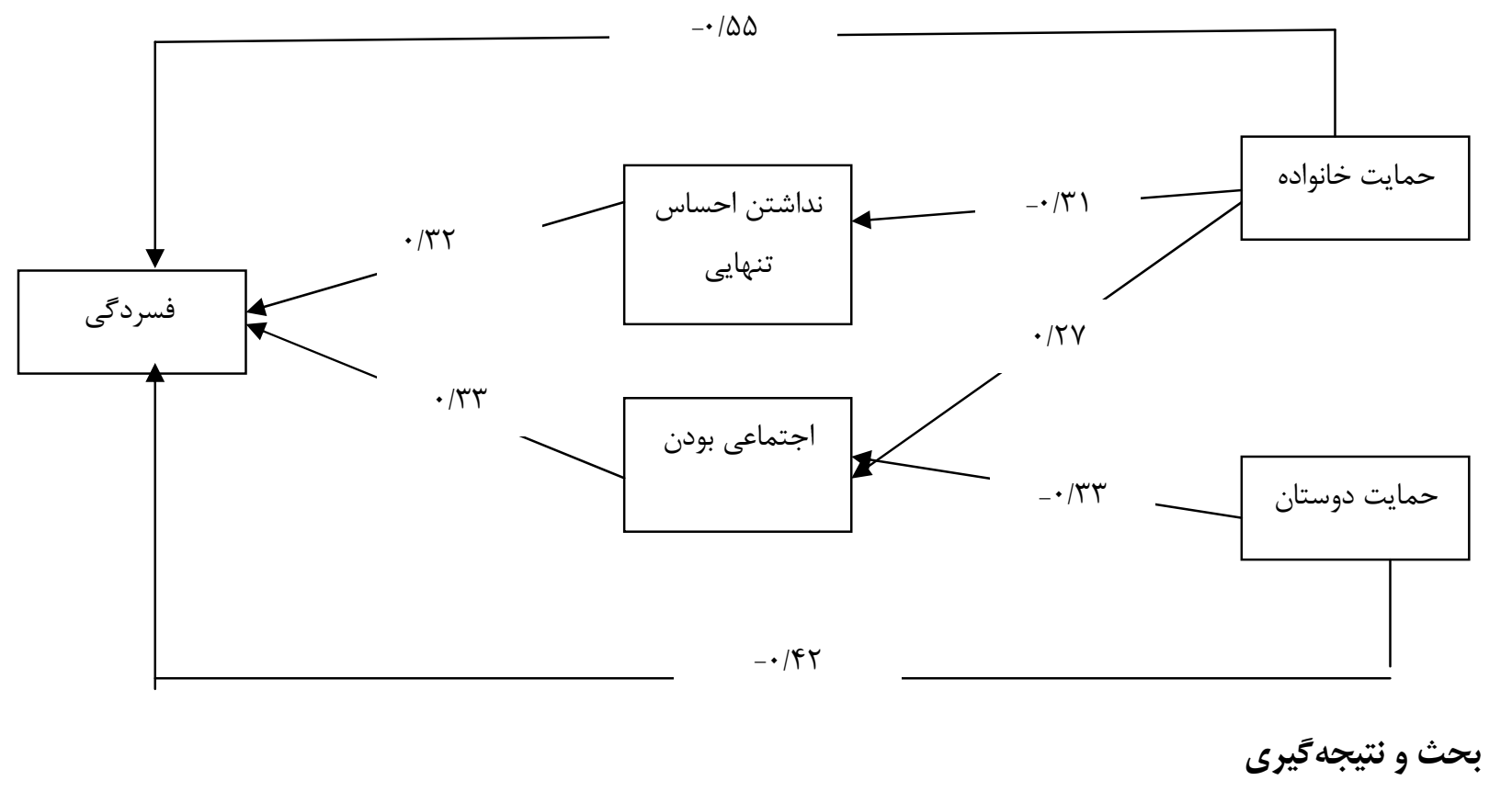

كرفته است. بدين منظور با توجه به ييشينه يزوهشى يـك مــل يزوهش حاضر با هدف بررسى رابطـهـه بــين حمايـت اجتمـاعى و مفهومى بيشنهاد و با استفاده از روش تحليل مسير مورد آزمـون افسردگى با توجه به نقـش واسـطهاى احسـاس تنهـايى انجـام 
فردى مثبت، يايدار و مهم در فـرد اسـت. اگرجهـه تفـاوت هـاى

فردى در شدت نياز تعلق داشتن و هُحونكى بـرآوردن آن وجـود دارد، ارضاء انى نياز مستلزم تعاملات مثبت وزياد با افراد ديخر در يكى موقعيت بادودام اسـت كـه منجـر بـهـ سـعادت و شـادكامى طرفين مى شود. بنابراين، افرادى كه در برقرارى و حفظ روابـط رضايت بخش با ديخران ناتوان هستند و در نتيجـهـ در بـرآوردن نياز تعلق داشتن مشكل دارند، احتمالا حس محروميتى را تجربه مى كنند كه خود را با احساس تنهايى نشان مى دهد. با توجه به مطالب مطرحشده مشخص است كه فرد سالمند اخر در برقرارى ارتباط اجتماعى با مشكل مواجه شود و يـا از حمايـت اجتمـاعى كافى برخوردار نباشد بـروز احسـاس تنهايى در او دور از تصـور نيست.

با نغاهى به مدل نهايى مى توان دريافت كـه احسـاس تنهايى توانسته نقش واسطهاى بين حمايت اجتمـاعى و افسـردگى ايفـا كند؛ بدين صورت كه اجتماعى بودن و نداشتن احساس تنهايى به صورت مثبت نقش واسطهاى ايفا مىنمايند. در كل مى توان به خانوادههاى داراى افراد سالمند يِيشنهاد نمـود كه در برقرارى روابطشان با اين افراد مراقب باشند كـه احسـاس ارزشمند بودن، علاقمند بودن به آنها را به آنها منتقل كنــــــهـ اين خود منجر به كاهش احساس تنهايى و در نهايـت كـاهش افسردگى مى شود. در نهايت در ارتباط با محدوديتهاى يزوهش مى توان كَفت با توجه به دامنه محدود مشاركت كنندكان در ايـن يزوهش از نظر سنى و جغرافيايى، لازم است در تعميم نتايج بـهـ ساير مناطق جانب احتياط را رعايت نمود. به دليل اينكه يزوهش از نوع همبستخى بود، نمىتوان از آن استنباط على نمود.
قرار كَرفت. نتــايج حـاكى از آن اسـت كـهـ متغيرهـاى يـروهش توانستهاند افسردگى را تبيين كنند. بدين صورت كه از ميان ابعاد حمايت اجتماعى دو بعد، حمايت خانواده بـا بتـاى هQه/ •- و بعـد حمايت دوستان با بتـاى זع/.•- بـه صـورت مسـتقيه و معنـادار

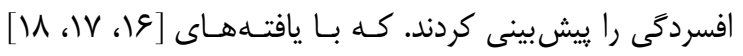
همخوانى دارد. در تبيين اين يافتهها مى توان مـواردى را مطـرح نمود از جمله اينكه حمايت اجتماعى يكسى از عوامـل اجتمـاعى تعيين كننده سـلامت روانسى اسـت، همجنــين انسـان موجـودى اجتماعى است و در طول حيات خويش نيازمند همنوعان خـود و برقرارى ارتباط با آنهاست. اگر فرد باور كند مورد احترام و علاقه ديخران است، عنصرى ارزشمند و داراى شـأن بـوده و بـهـ يـــ شبكه روابط و تعهدات متقابل تعلق دارد، اين باورهـا در نهايــ

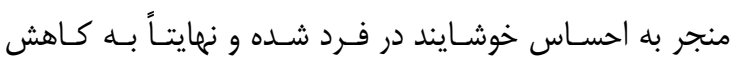
افسردگى مى انجامد. در صورتى كـه اخـر فــرد از منبـع حمـايتى برخوردار نباشد و اين باور در او ايجاد شود كه تنهاسـت و كسـى براى او ارزشى قائل نيست و براى برقـرارى ارتبــاط بـا ديعــــان مردد باشد در نتيجه انتظار مىرود كه فرد دجار افسردگى شود. نتايج ديخر حاكى از آن بود كه احساس تنهايى افراد تحت تـأثير حمايت اجتماعى قرار دارد، بدين صورت كـه حمايـت خـانواده و حمايت دوستان دو بعد اجتماعى بودن و نداشتن احساس تنهايى را ييشبينى كردند كه با يزوهش هاى [ 19 + +1] همخوانى دارد. در اين خصوص مىتوان كفت كه انسان ماهيتى اجتماعى دارد و از بدو تولد اين گرايش در او وجود دارد. همجِنين نياز بـه تعلـق داشتن، در انسان يك انغيزه اساسى را شكل مى دهد كه باعث افكار، هيجانات و رفتارهاى بين فردى مى شود. اين نياز شـامل

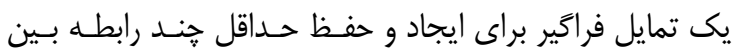




$$
\text { حرق تقدير و تشكر }
$$

\section{- References}

1.Pymanfr, E. Lyakbrydhkrdy, M. Mohtashami, T. Compare loneliness and a sense of meaning in life of elderly people with different levels of religious attitudes. Psychology and religion 2013; 5(4): 52-41.

2.Shahbazzadegan B, Farmanbar R, Ghanbari A, Atrkar Z, Adib M. [The Effect of Regular Exercise on Self-esteem in Elderly Residents in Nursing Homes] Journal of Ardabil University of Medical Sciences \& Health Services 2007; 4(8): 387-393.[Persian].

3.Sajadi H, Biglarian A. [Quality of life among elderly women in Kahrizak charity Foundation, Tehran, Iran. Payesh], Journal of The Iranian Institute For Health Sciences Research 2007; 2(6): 105-108.[Persian].

4.Riahi A. [Comparative study of the position and status of elderly people in the past and contemporary societies. Salmand, Iranian], Journal of Ageing 2009; 3(9-10):9-21.[Persian].

5. Abrahami.A. (1382). The relationship between depression in nursing home residents with attitude and practice their faith. Monthly Research in Medical Sciences2004; 8.

6.Norton MC. church attendance and new episodes of major depression in a community study of older adults. The journals of gerontology 2008; 63 B,3.

7.Hagop S akiskal. Mood disorders: Clinical Features.In: Sadock BJ, Sadock VA .Kaplan \& Sadock,s comprehensive textbook of psychiatry 8th ed. Philadelphia: Lippincot willaims \& Wilkins. 2005; 1559-1717.

8.Hawton k, Salkovskis PM, Kirk J, Clark DM. Cognitive behavior therapy for psychiatric problems: a practical guide. 1th ed. Oxford: oxford university press, 1989.

9.Kleinke CL. [Coping with life challenges. 2nd ed]. Tehran: The Resane Takhasosi Press 2007; (Persian).

10.Cohen S, Wills TA.(1985). Stress, social support, and the buffering hypothesis. Psychol 
Bull 1985; 98: 310-357.

11.Kilpatric R. Support, Social, relationships and mental health. Physical Medicine and Rehabilitation 2005; 364-349.

12.Moore RG, Garland A. Cognitive therapy for chronic and persistent depression. 1rd ed. New York 2003; John Wiley \& Sons Ltd.

13.Cobb, S. Social Support as a moderator of life stress. Psychosomatic Medicine 1976; 38: 300-314.

14.Lang AJ, Stein MB. Anxiety Disorders: How to recognize and treat the medical symptoms of emotional illness. Gerircs 2001; 56(5) : 24-7 \& 31-4.

15 Alipur, F. Sajadi, H. . Frouzan.A, Nabavi. H, KHedmatiI, I. [The role of social support on anxiety and depression in the elderly]. Journal of elderly2010; 4(11) 61-53. (Persian).

16. Wang H, Wu SZ, Liu YY. Assocation between social support and health outcomes: ameta-analysis. The Kaohsiung journal of medical sciences 2003; 19( 70): 345-350.

17. Zimmer. Z, Chen. F. Social Support and Change in Depression Among Older Adults in Taiwan. Journal of Applied Gerontology 2012; 31 (6).

18. Kendler. KS, Myers. J, Prescott. C. Sex Differences in the Relationship Between Social Support and Risk for Major Depression: A Longitudinal Study of Opposite-Sex Twin Pairs, The American journal of psychiatry 2005; 162 (2): 250-256.

19. Leskela. U, Rytsala. H, Komulainen. E, melartin. T. The influence of adversity and perceived social support on the outcome of major depressive disorder in subjects with different levels of depressive symptoms. Journal of psychologhical medicine 2006; 36 (6): 779-788.

20. Mo'tamedi Shalamzari A, Ezhei J, Azad Falah P, Kiyamanesh A. [The Impact social support in life satisfaction, general health and isolation feeling in older adults above 60 age]. Journal of Psychology 2008. 6(2):45-62. (Persian).

21.Hemati Alamdarlo G, Dehshiri GH, Shojaee S,Hakimirad E. [Health and loneliness Status of the Elderly Living in Nursing Homes Versus Those Living with Their Families Salmand], Iranian Journal of Ageing.2008;3(8):557-68.(Persian).

22. R. F., \& Leary M. R.The need to belong: Desire for interpersonal attachments as a fundamental human motivation.Psychological ulletin. 1995; 117:497-529. 
23. Henrich L. M., \& Gullone E. The clinical significance of loneliness: A literature review. Clinical Psychology Review. 2006; 26: 695-718.

24.Heravi-karimooi M, Anoosheh M, Foroughan M, et al. Loneliness from the perspectives of elderly people: a phenomenology study.Iranian journal of ageing.2007;2(6):410-420. (Persian).

25. Shearer, R., Davidhizar, R. Conquering loneliness", Elder Care 1999; 2: 12- 15.

26.Peplau L. A. Perceived dimensions of attribution for loneliness. Journal of Personality and Social Psychology. 2007; 43: 929-936.

27.Wiseman ,H., et al. (2006) Why are They Lonely?Perceived Quality of Early Relationship with Parents, Attachment,Personality Predispositions and Loneliness in first-yaer University Students, Personality and Individual Differences 2006; 40: 237- 248.

28. Behrouzi.N, SHeheniyeylagh. M, poursayed.M. [Relationship between Perfectionism, perceived stress and social support, academic burnout], Culture Strategy Magazine 2013; 20.(Persian). 